\title{
ELEPHANT CONTROL IN NATIONAL PARKS
}

\author{
A New Approach \\ By U. DE V. Pienaar, Ph.D. \\ (Biologist, Skukuza, Kruger National Park) \\ and \\ J. W. VAN NIEKERK, B.V.Sc. \\ (State Veterinarian, Skukuza, Kruger National Park)
}

The African continent with its remarkable wealth of large mammals represents a zoological community which is unique in the world. For many centuries it has been a hunter's paradise and since the dawn of human history in Africa, the wild animals of this vast continent were hunted by primitive man. Despite the toll taken by the super-predator the great herds of game encountered by the earliest European explorers bore ample testimony to the supposition that man and beast subsisted in perfect harmony in their chosen habitats, and the primitive hunter in fact occupied an important niche in the natural order.

With the advent of European penetration by the early settlers and explorers, the stage was set for the first dominating intervention by man in the biological life of the continent, and the subsequent period witnessed a progressive disturbance of the existing natural equilibrium.

The introduction of fire-arms, and at a later stage, of the wire snare, to the pristine scene, heralded an era of appalling slaughter of game. The ravaging of Africa's natural resources grew with man's increasing intelligence, and civilization with its expanding industrial and agricultural development spelled the death-knell of free-roaming game in many areas.

The ever-dwindling game herds were continually pushed back before the advances of the white man's progress in Africa, and retreated to the relatively few wild and unexploited regions still accessible to them.

The extinction of a number of species in quick succession fortunately brought home the unavoidable fate and desperate plight of the pitiful remnants of African game to the later generations, and at the turn of the 20th century certain areas were set aside and entrenched by legislation for the protection and continued survival of the remaining species of game animals.

The African elephant (Loxodonta africana Blumenbach) in the Republic of South Africa found sanctuary in the Kruger National Park and the Addo Elephant Park of the Eastern Cape.

The boundaries of the Kruger National Park, an area of some 7,500 square miles in extent, have recently been entailed on its southern, western, northern and portions of its eastern limits by a 6 foot high game fence. This fence is reinforced in parts with heavy cable for the purpose of preventing elephants from wandering onto the adjacent agricultural areas and Trust lands.

The elephant camp in the Addo National Park covers an area of about 9 sq. miles and is completely surrounded by an elephant-proof fence. 
The most recent census of elephants (1962) set their number at 1,750 in the Kruger National Park. This substantial population has grown from an original nucleus herd of no more than ten in 1905, supplemented by immigrants from Portuguese East Africa over the years.

There are at present also thirty-four of the Addo elephant race in the Cape Park, but there were only a dozen animals left in this area at the time of proclamation in 1931.

In view of our inadequate knowledge of the reproductive potential, migrating habits and food requirements of the African elephant under varying ecological conditions, it is difficult to assess the optimum carrying capacity of the areas in which they are protected. It is safe to assume however, that these great beasts, having been deprived of their natural predator (primitive man), and with disease as its only remaining controlling factor (Pienaar, 1961), are bound to increase excessively in numbers, with subsequent overcrowding and deterioration of the confined habitat.

Although there are at present no qualms about an over-population of elephants, in the immediate future, in either the Kruger National Park or the Addo Park, the grave dangers of overstocking loom ahead, and the time is foreseen when the rapidly expanding herds will have to be artificially controlled in order to safeguard the wellbeing and health of their respective populations.

Elephants in the Kruger National Park are at present only destroyed on account of severe injuries, where the prognosis is unfavourable, or in the case of wounded beasts with aggressive tendencies.

A few habitual fence breakers and crop raiders, and those doing excessive damage to rest camps, are also destroyed.

The control of elephant numbers by selective hunting with rifles is not regarded as a suitable practice in National Parks, and may indeed be highly dangerous. A National Park is, apart from its scientific, aesthetic and cultural value, also an important tourist attraction, and a wounded and aggressive elephant may create havoc and cause loss of life amongst the heavy tourist traffic in an area such as the Kruger National Park.

A second objection to this method of hunting is that the report of heavy calibre rifles invariably stampedes the remainder of the herd, and these intelligent beasts very soon associate man with danger. This in turn engenders punitive and vindictive traits, destroying completely the present docile and amicable relationship between man and beast.

The selective cropping of a herd is a very important aspect of elephant control. A method whereby a particular animal may be destroyed without disturbing the herd would therefore be most desirable.

The Nature Conservation Department of the Kruger National Park has recently initiated field trials to devise an effective but safe method of elephant control under local conditions. Only one animal has so far been destroyed by this method, but experiments will be continued as the opportunity affords itself.

Harthoorn et al (1961) reported on the handling and marking of African elephant by means of the drug immobilizing technique. The drugs used in these experiments were Succinyl-choline chloride ("Scoline") and Gallamine triethiodide. The latter was found to be superior to "Scoline" 
on account of its more gradual onset of paralysis and the fact that its action is largely reversible.

Succinyl-choline chloride on the other hand was found to have a very narrow safety margin, and did not appear to be the ideal immobilizing agent (Harthoorn et al. 1961).

In the light of these findings it was decided by us to utilize the crossbow and projectile-syringe as a weapon for elephant control, with "Scoline" as the paralysing agent. (Succinyl-choline chloride is a muscle relaxant acting by persistent depolarization of the motor end plates.)

A young adult elephant bull with an approximate body weight of 7,766 lbs. and accompanied by a larger bull, was selected whilst feeding on reeds on a river bank. The animal was darted from a distance of 35 yards with a projectile-syringe, containing $4.5 \mathrm{gm}$. "Scoline". Both animals were unaware of our presence, and the slight resonance of the bow-string was apparently not heard. The stricken beast did not reveal any sign of reaction on impact of the dart, and kept on grazing. The dart struck the animal at an angle on its hindquarters. It was obvious that the needle did not pierce the skin, and a second dart (containing 3.3 gm. "Scoline") was fired 15 minutes after the initial shot. The elephant started slightly after being struck by the second dart, walked a few yards, and then continued feeding. Five minutes after the second dart was fired the animal suddenly stopped in its tracks, tottered on its legs and dropped about 100 yards from the original site.

The animal was completely immobilized; its respiration irregular and shallow. Except for a rattle in the throat, and slight convulsions of the trunk, the animal remained absolutely silent and died 30 minutes later. The other elephant was still grazing contentedly about 100 yards from the paralysed animal, completely unaware of what happened to its comrade.

\section{Discussion}

The application of the immobilizing technique as a method of elephant control merits further investigation. The results achieved in the destruction of a single animal by administering an overdose of "Scoline" proved that a theoretically sound method can be effectively utilized in practice.

The advantages of this technique as compared to conventional methods are obvious :-

(i) The method is humane and it is impossible to wound or lose an animal darted with an overdose of Succinyl-choline chloride. If the weight of the animal had been under-estimated, it will either not react at all, or will recover after being temporarily immobilized. It should therefore be the method of choice in a National Park where wounded and aggressive animals may endanger the lives of staff and tourists.

(ii) Shooting with a crossbow and projectile-syringe causes no panic or alarm in a herd and will consequently cause the minimum disturbance in their normal behaviour and movements.

(iii) This method will render selective cropping of an elephant herd much less arduous.

(iv) A total volume of 10 to $15 \mathrm{ccs}$. of "Scoline" at a concentration of 
$500 \mathrm{mgm} / \mathrm{cc}$. will effectively kill an animal with a body weight of 5 tons. According to Harthoorn and his co-workers the effective immobilizing dose for elephants is approximately $0.3 \mathrm{mgm} / \mathrm{lb}$. In view of the critical dosage rate of "Scoline" a dose of 0.5 to $0.75 \mathrm{mgm} / \mathrm{lb}$. should be ample to paralyse the animal's respiratory muscles completely.

(v) Shooting with the crossbow from a larger distance (35 to 50 yards) than is the practice with heavy calibre rifles, is much safer for the staff members entrusted with the task of elephant control.

(vi) More than one animal can be destroyed by this method at the same time and place. Darting three or four (or even more) animals successively should not cause undue alarm amongst a herd.

(vii) The same basic equipment used for the capture of hippos, rhinos and other thick-skinned animals can be utilized for this purpose and the expense involved is not prohibitive. The equipment used in this initial experiment is the same as that described by us in a previous publication. (Van Niekerk and Pienaar, 1962).

(viii) The meat of an animal killed in this way is edible, as "Scoline" is easily destroyed by heat and is not effective when taken per os.

\section{REFERENCES}

ANoN (1957). Annual Report of the Game and Fisheries Department of Uganda Protectorate for the period 1st Fuly, 1956 to 30th Fune, 1957. pp..19-26.

BUECHNER, H. K. and H. C. Dawkins. (1961). Vegetation change induced by elephants and fire in Murchison Falls. Ecology, Vol. 42, No. 4, pp. 752-766.

Buss, I. O. (1961). Some observations on food habits and behaviour of the African elephant. Fnl. of Wildlife Management, Vol. 25, No. 2, pp. 131-148.

Fraser-Daring, F. (1960). Wild life in an African Territory. Oxford University Press. London.

HARTHOORN, A. M., J. A. LOCK, and C. P. LUCK. (1961). Handling and marking of wild African elephants (Loxodonta africana) with the use of the drug immobilizing technique. The British Vet. Fourn., Vol. 117, No. 2, pp. 87-91.

PIENAaR, U. DE V. (1961). A second outbreak of anthrax amongst game animals in the Kruger National Park. Koedoe, No. 4, pp. 4-18.

VAN NIEKRRK, J. W. and U. DE V. PIENAar. (1962). Adaptations of the immobilizing technique to the capture, marking and translocation of game animals in the Kruger National Park. Koedoe, No. 5, pp. 137-144.

Worthington, E. B. (1961). The Wild Resources of East and Central Africa. Her Majesty's Stationery Office, London. 